\title{
Distanční výuka při opatřeních spojených s koronavirovou pandemií - pohled očima učitelů, žáků a jejich rodičů
}

\author{
Lukáš Rokos ${ }^{a}$, Michal Vančura ${ }^{b}$
}

a Jihočeská univerzita v Českých Budějovicích, Pedagogická fakulta, Katedra biologie

b Jihočeská univerzita v Českých Budějovicích, Pedagogická fakulta, Katedra geografie

Redakci zasláno 8. 6. 2020 / upravená verze obdržena 6. 10. 2020 /

k uveřejnění přijato 17. 9. 2020

\begin{abstract}
Abstrakt: Cílem prezentované studie bylo zjistit, jaké jsou pohledy aktérů vzdělávacího procesu na distanční výuku, která byla plošně zavedena ve spojitosti s epidemií koronaviru. Za tímto účelem byl připraven vlastní dotazník, který byl následně distribuován učitelům, rodičům a žákům vybrané základní školy v Jihočeském kraji. Celkem bylo od všech skupin respondentů prostřednictvím Google Forms získáno 522 dotazníků (29 od učitelů, 255 od rodičů a 238 od žáků). Bylo zjišt’ováno, jakým způsobem je zajištěna komunikace mezi jednotlivými skupinami respondentů, kolik času jim zabere příprava, plnění a kontrola zadaných úkolů, které předměty vnímají žáci jako nejobtížnější, ale zjištóován byl i subjektivní pohled všech skupin respondentů na distanční výuku. Ukázalo se, že na sledované škole bylo díky technickému zajištění zapojení žáků kompletní. Problémem však byla míra jejich zapojení a celková aktivita v distanční výuce. Učitelé pro komunikaci se žáky i rodiči používali různé platformy a aplikace, což se pro dlouhodobější řešení distanční výuky jeví jako nevhodné. Jako další riziko pro úspěšnou realizaci distanční výuky se jednoznačně jeví absence metodické podpory pro rodiče žáků. Ačkoliv vzhledem k náhlosti situace spolupráce na dané škole probíhala téměř bez obtíží, realizovaná sonda odkrývá oblasti, na které by se mohl zaměřit další pedagogický výzkum.
\end{abstract}

Klíčová slova: covid-19, distanční výuka, výuka doma

Onemocnění covid-19 bylo prohlášeno Světovou zdravotnickou organizací (WHO) za pandemii 12. března 2020 (WHO, 2020). Ve spojitosti s rychlým šířením koronavirové nákazy začala být realizována různá opatření, at' již ve snaze omezit rychlost a rozsah nákazy či zmírnit její dopady na společnost (Hale et al., 2020). V den vyhlášení pandemie byly uzavřeny školy ve 49 zemích světa či na jejich územních celcích (UNESCO, 2020a). Vláda České republiky vyhlásila nouzový stav o den dříve (Vláda ČR, 2020), tj. 11. března 2020 , kdy byly zavřené školy teprve ve 27 zemích na světě. Spousta zemí postupně reagovala stejným způsobem, takže začátkem dubna bylo uzavřením škol ovlivněno více než 1,5 miliardy dětí a mladistvých (UNESCO, 2020a). 
V České republice byl první př́ípad onemocnění covid-19 zaregistrován 1. března 2020 (MZČR, 2020a), na což decizní sféra reagovala velkým množstvím postupně vydávaných opatření. Jedním z opatření bylo již zmíněné uzavření škol (MZČR, 2020b), které výrazně zasáhlo vedení škol, učitele, žáky i jejich rodiče. Spousta rodičů musela zůstat s dětmi ze dne na den doma, což působilo problémy $\mathrm{v}$ různých odvětvích ekonomiky. Výuka se přesunula do virtuálního prostoru ve zcela zásadní míře, v jaké nebyla nikdy testována, natož realizována. Cílem naší studie bylo zjistit, jak na vzniklou situaci bezprostředně reagovali učitelé, žáci a jejich rodiče na konkrétní vybrané základní škole a jakým způsobem se změnil styl jejich práce.

\section{Reakce na pandemii covid-19}

V následujícím textu jsou citovány převážně zahraniční zdroje, zejména asijských autorů. Důvodem je skutečnost, že asijské země mají větší zkušenosti s pandemickými onemocněními a se strategiemi jejich zvládání. Zároveň se onemocnění covid-19 projevilo v těchto zemích dříve než v Evropě, tudíž jsou zde již dostupná určitá předběžná data či ověřené postupy. Je však potřeba brát v potaz, že pandemické zkušenosti asijských zemí vycházejí ze zcela odlišných vzdělávacích podmínek, tudíž prezentovaná řešení či reakce aktérů výchovně-vzdělávacího procesu mohou být značně specifické.

Viner s kolektivem (2020) provedli rešerši téměř 500 příspěvků, které se vztahovaly $\mathrm{k}$ výuce $\mathrm{v}$ době pandemie. Tři příspěvky se týkaly přímo covid-19, zbývající se zaměřily převážně na pandemii SARS v roce 2003 (Viner et al., 2020). Různí autoři (např. Uscher-Pines et al., 2018; Yen et al., 2014) argumentují, že existují zavedené způsoby, jak udržovat sociální distanc bez nutnosti kompletního uzavření škol. Oba autoři čerpají ze zkušeností vybraných států s předchozími pandemiemi, ale shodují se na tom, že se těmto již vyzkoušeným postupům věnovala $v$ současné době poměrně malá pozornost. Např́íklad Taiwan v období pandemie H1N1 v roce 2009 zavedl místo celkového uzavření škol opatření zajištujuící vyšší sociální distanc, ale bez výrazného narušení sociálních interakcí mezi jednotlivými aktéry vzdělávacího procesu (Uscher-Pines et al., 2018; Yen et al., 2014).

Příkladem zajímavého programu při pandemii covid-19 je plán čínského ministerstva školství s názvem School's Out, but Class's On (lze přeložit jako „Mimo školu, ale přesto ve třídě“), které se takto snažilo snížit negativní dopad uzavření škol na výuku (Cheng, 2020; Ministry of Education of the People's 
Republic of China, 2020). Program obsahuje sedm hlavních podmínek pro úspěšné zvládnutí výuky na dálku a některé z níže prezentovaných bodů se shodují i s doporučeními, které vydalo české Ministerstvo školství, mládeže a tělovýchovy (dále jen MŠMT):

1) Zajistit správné vedení žáků při domácí výuce. Je nezbytné vyvážit aktivní čas strávený studiem a odpočinkem.

2) Standardizovat online činnosti tak, aby nebyla abnormálně zvýšena pracovní zátěž učitelů a žáků.

3) Nadále zlepšovat vytváření online platforem pro základní a střední školy a neustále do nich doplňovat nové zdroje. Snažit se tímto způsobem zabránit tomu, aby se metody, činnosti a časové harmonogramy klasických prezenčních hodin aplikovaly $\mathrm{v}$ distanční výuce.

4) Klást větší důraz na recenzování online výukových prostředí a elektronických materiálů k zajištění jejich kvality.

5) Plně využívat bezplatné výukové zdroje, platformy poskytované různými organizacemi a institucemi (např. státní televize), které mohou efektivně sloužit žákům (nejen) v odlehlých oblastech.

6) Zahrnout zásady prevence epidemie, bezpečnosti, mentálního zdraví a psychohygieny do online výuky.

7) Zajímat se o fyzický i mentální stav žáků, vést žáky k tomu, aby prováděli i fyzické aktivity a neseděli pouze u obrazovky, čímž lze zlepšit i prevenci rozvoje vad zraku.

UNESCO (2020b) připravilo portál pro podporu distanční výuky, na němž byly učitelům prezentovány různé postupy, jak zajistit výuku na dálku. MŠMT (2020a) vydalo podobný soubor doporučených postupů a zároveň společně s Národním pedagogickým institutem spustilo portál „Vzdělávání \# NaDálku“ (MŠMT, 2020b), na němž lze nalézt odkazy na různé webináře, postupy a rady pro komunikaci s žáky, tipy a nápady do výuky a odkazy na příklady dobré praxe. Aktivně se zapojila také Česká televize, která spustila 16. března vysílání pro žáky prvního stupně (Česká televize, 2020), a další (nejen) vzdělávací instituce vytvořily prostředí pro sdílení vzdělávacích materiálů či zpřístupnily licencované elektronické zdroje, které jsou běžně placené. Pro ilustraci uvádíme i př́íklady vybraných portálů v zahraničí, například 
ve Finsku je k dispozici portál Koulu.me ${ }^{1}$, na kterém řada společností vyvíjejících technologie použitelné ve vzdělávání nabízí zdarma přístup ke svým produktům. Př́kladem dobré praxe je Estonsko, které se intenzivně věnuje digitalizaci (nejen) výukových materiálů, což se v souvislosti s pandemií covid-19 velmi vyplatilo. Iniciativa Education Nation ${ }^{2}$ připravila web, na kterém lze nalézt odkazy na rozmanité digitální zdroje, nástroje použitelné ve výuce, manuály pro učitele apod. Metodickou podporu pro učitele prezentuje také německý portál Das Deutsche Schulportal ${ }^{3}$ či detailně propracovaný britský portál BBC Bitesize ${ }^{4}$, na němž lze nalézt výukové jednotky pro všechny stupně vzdělávání, včetně materiálů pro žáky i metodických pokynů pro učitele.

\section{Distanční vzdělávání}

Distanční vzdělávání je jakákoliv forma studia, při níž není studující jedinec pod neustálým dohledem učitele, ale má k dispozici plán, možnost konzultací a je učitelem veden na dálku (Průcha \& Míka, 2000; Všetulová et al., 2007). „Cílem distančního vzdělávání je umožnění se průběžně vzdělávat jedincům, kteří se nemohou účastnit prezenční (kontaktní) formy vzdělávání.“ (Zlámalová, 2007, s. 30).

Distanční vzdělávání a jeho různé varianty zaznamenaly úspěch spíše v zahraničí a u žáků staršího školního věku či studentů vysokých škol. Často je tento přístup prezentován jako vhodný doplněk klasické školní docházky (např. Kennedy \& Ferding, 2018; Simonson et al., 2019). V českém vzdělávacím prostředí byl umožněn $v$ 90. letech rozvoj duálního systému, tudíž vzdělavatelé mohou výuku realizovat $\mathrm{v}$ prezenční i distanční formě studia (viz §25 561/2004 Sb. a navazující předpisy); distanční forma se nicméně využívala zejména při vzdělávání dospělých. V srpnu 2020 byl školský zákon novelizován a došlo k zavedení pravidel pro vyhlášení distanční výuky.

Mezi přednosti distančního vzdělávání lze zařadit časovou a obsahovou flexibilitu, různé způsoby poskytování zpětné vazby, vysokou míru individualizace, zejména ve vztahu k možnosti zvolení si vlastního tempa učení se, a využití rozmanitých informačních a komunikačních technologií (Bednaříková, 2013; Kalhous \& Obst, 2002; Zlámalová, 2007). Rizika a problémy spojené

\footnotetext{
https://koulu.me/

https://www.educationnation.ee/

https://deutsches-schulportal.de/

https://www.bbc.co.uk/bitesize
} 
s užitím distančního vzdělávání lze vztáhnout k osobě vzdělavatele a osobě studujícího jedince. Na straně vzdělavatele to jsou aspekty spojené $s$ prrípravou a organizací této formy vzdělávání, nutnost mít specifické technické dovednosti a znalosti, náročná př́prava a nutnost důkladného promyšlení způsobů hodnocení (Maier et al., 1998; Zlámalová, 2007). Na straně učících se jedinců se jedná např́klad o nedostatečnou motivaci, nezkušenost s touto formou vzdělávání a nedostatečné dovednosti v užívání různých technologických prostředků (Bednaříková, 2013; Zlámalová, 2007).

Cheng (2020) charakterizuje limity spojené s užitím distančního vzdělávání v rámci výuky při pandemické situaci spojené s onemocněním covid-19: 1) výzvy spojené s tradičním způsobem vzdělávání, 2) výzvy spojené s učitelovým osobním pojetím výuky, 3) výzvy spojené s různými učebními styly žáků, 4) výzvy spojené s nutností inovovat výukové zdroje a v neposlední řadě 5) výzvy spojené s administrativními úkony ve škole. Zcela konkrétní problém, se kterým se musely školy vypořádat, bylo zajištění přístupu všech žáků $\mathrm{k}$ výuce. $\mathrm{V}$ mnoha př́ípadech se projevily nedostatky související s technickým vybavením učitelů i žáků, dostupností kvalitního internetového připojení pro online výuku či potřebnou softwarovou podporou pro užití různých elektronických materiálů (Xie \& Yang, 2020). Dalšími klíčovými faktory jsou množství času, který rodiče věnují výuce svých dětí, a také jejich kognitivní úroveň (Oreopoulos, 2006). Je obtížné vysvětlovat dětem problematiku učiva, kterému sám rodič zcela nerozumí (Brom et al., 2020). Rodiče také nemusí přesně vědět, jak danou látku svým dětem jednoduše zprostředkovat.

Materiály pro distanční výuku je vhodné připravit takovým způsobem, aby rozvíjely autonomní učení žáků (Xie \& Yang, 2020). Pokud si žáci mohou samostatně určovat vlastní strategie učení, může dojít k celkovému zlepšení jejich výkonu, protože si zvolí strategii, která je jim blízká (Zhou \& Li, 2020). Vhodné je materiály vztahovat k praktickým záležitostem každodenního života žáka, aby si uvědomoval užitečnost daných informací, učil se pracovat s různými zdroji, tř́́dit informace, navrhovat vlastní postupy, a osvojoval si tak nové praktické dovednosti (Hesson \& Shad, 2007). Je však nutné zdůraznit, že materiály, které vznikaly při distančním vzdělávání zavedeném v souvislosti s opatřeními spojenými se šířením covid-19, nelze označit např́klad za e-learningové materiály, jelikož učitelé museli vytvářet materiály pro výuku ve velmi krátkém čase, tudíž nejsou pilotně ověřené a následně upravené do finální podoby. Kritická evaluace vytvářených e-learningových 
materiálů je nezbytnou prerekvizitou zajištění kvality a efektivity těchto materiálů (Eger, 2004).

\section{Aktuální empirické studie}

V souvislosti s koronavirem došlo ve většině zemí k úplnému uzavření škol, které trvalo déle než měsíc. V současné době stále není možné vyvodit dopad tohoto uzavření, jelikož nejsou k dispozici relevantní data (Kwok et al., 2020; Sintema, 2020). Většina odborné literatury vztahující se k onemocnění covid-19 je lékařského charakteru (např. Wu \& McGoogan, 2020; Zu et al., 2020) nebo představuje různé scénáře dopadu na ekonomiku či cestování (např. Chinazzi et al., 2020; Kraemer et al., 2020). Z dostupných zdrojů zaměřených na vzdělávání se jedná nejčastěji o dokumentování pohledu účastníků vzdělávacího procesu v průběhu distančního vzdělávání. Studie jsou většinou lokálně specifické, protože jednotlivé státy se postavily k uzavření škol různým způsobem, tudíž autoři analyzují informace vztahující se ke konkrétnímu školskému systému.

V případě České republiky jsou získaná data vyhodnocována a připravována $\mathrm{k}$ publikaci, popř́padě jsou $\mathrm{k}$ dispozici pouze předběžné závěry. Zmínit lze výsledky dotazníkového šetření, které provedla Česká školní inspekce (ČŠI) mezi 4861 řediteli základních a středních škol, v němž přibližně tři čtvrtiny ředitelů uvedly, že žáci na jejich školách s učiteli komunikovali (ČŠI, 2020). Ačkoliv většina učitelů nepoužívala online prostředí při běžné výuce, tak nově vzniklá situace se pro ně stala výzvou a větší procento učitelů tento způsob začalo aktivně používat (ČSI, 2020). Další závěry z této studie, které Česká školní inspekce vydala v podobě tematické zprávy, srovnáváme následně v diskuzi s našimi zjištěními. V další studii (viz Brom et al., 2020) bylo dotazováno téměř 10 tisíc rodičů českých žáků, jakým způsobem spolupracují se školami, jak zvládají výuku doma a co spatřují jako největší problémy distanční výuky. Ukázalo se, že 91 \% rodičů se domnívalo, že vzdělávání doma zvládají (Brom et al., 2020), ale zároveň bylo možné identifikovat tři kategorie nejčastěji uváděných problémů spojených s distanční výukou, konkrétně 1) nedostatek času, 2) omezené materiální vybavení, 3) nedostatek odborných vědomostí a pedagogických dovedností na straně rodičù (Brom et al., 2020). Závěry této studie opět porovnáváme v diskuzi s našimi výsledky. 


\section{Metodologie výzkumu}

Naše studie je úvodní sondou, která mapovala situaci na dané škole v počátečních týdnech vyhlášení nouzového stavu. Soustředili jsme na tři základní oblasti: technické zajištění distanční výuky, využívání zdrojů a práci se zdroji při distanční výuce, časovou potřebu pro distanční výuku (tzn. kolik času věnují žáci, potažmo i rodiče, výukovým aktivitám a řešení zadaných úkolů). Cílem také bylo zjistit, jak vnímají distanční výuku jednotlivé skupiny aktérů výchovně-vzdělávacího procesu, včetně uvedení pozitivních a negativních stránek této formy výuky z jejich pohledu.

Dalším cílem bylo identifikovat oblasti pro případný další výzkum. $V$ tomto př́ipadě je však nutné hned v úvodu říci, že sběr dat probíhal v dubnu, kdy ještě bylo těžké odhadnout, jak dlouho bude distanční výuka trvat, tudíž naši respondenti reflektovali aktuální situaci.

\subsection{Vzorek respondentů}

Studie byla realizována na vybrané základní škole v Jihočeském kraji. Škola chtěla zjistit postoje učitelů, žáků a rodičů a obrátila se sama na výzkumníky s možností spolupráce na tomto šetření. Škola dlouhodobě spolupracuje s Pedagogickou fakultou Jihočeské univerzity v Českých Budějovicích při realizaci výzkumů a projektů. Z důvodu zachování anonymity je však uvedena pouze charakteristika dané školy. Jedná se o typickou, státem financovanou základní školu městského typu, jejímž zřizovatelem je město s přibližně 10 tisíci obyvateli. Součástí školy je odloučené pracoviště v městské části, které je málotřídní školou. Celkem má škola 22 tříd, které navštěvuje necelých 500 žáků, z nichž jsou u necelých 10 \% identifikovány speciální vzdělávací potřeby (stav k 31.1.2020). Výuka je zajištěna 33 učiteli (z toho 31 učitelů je kvalifikovaných a 28 učitelů má plný úvazek). Z hlediska žákovské, resp. rodičovské klientely se jedná o školu standardní s minimálním zastoupením sociálně slabých rodin.

Byly rozlišovány tři profily respondentů. První skupinou byli žáci dané školy, konkrétně žáci prvního stupně ( $\mathrm{N}=81$, z toho 47 dívek a 34 chlapců) a žáci druhého stupně $(\mathrm{N}=157, \mathrm{z}$ toho 93 dívek a 64 chlapců). Druhou skupinu představovali rodiče žáků (164 rodičů žáků z prvního stupně, z toho 13 mužů a 151 žen; 91 rodičů žáků z druhého stupně, z toho 5 mužů a 86 žen) a třetí skupinou byli učitelé ( $N=29$, z toho 5 mužů a 24 žen). 


\subsection{Sběr dat}

Pro sběr dat byly použity autorské polostrukturované dotazníky (Gavora, 2010) vytvořené v aplikaci Google Forms, konkrétně tři verze, z nichž jedna byla určena pro žáky (Příloha 1), druhá pro jejich rodiče (Příloha 2) a třetí pro učitele (Příloha 3). Dotazováni byli žáci ze 4.-9. ročníku. U žáků mladšího věku bylo usouzeno, že by pro ně vyplnění dotazníku bylo příliš obtížné a nejspíše by odpovědi uváděli místo žáků jejich rodiče. Dotazník pro žáky prvního a druhého stupně se lišil zcela minimálně. $V$ dotazníku pro mladší žáky byly vypuštěny předměty, které se na prvním stupni základní školy nevyučují, a zjednodušeny formulace v zadání některých otázek, aby byly pro respondenty snáze pochopitelné. Dotazníky převážně obsahovaly uzavřené výběrové položky, škálové položky a doplňkově otevřené položky s možností stručné odpovědi.

Celá studie probíhala se souhlasem vedení školy. Pro snadnější vyhodnocení byl pro každou tř́́du použit jedinečný odkaz, tudíž bylo možné rozdělit odpovědi žáků a rodičů z jednotlivých tříd. Odkaz byl žákům, rodičům i učitelům zaslán prostřednictvím portálu Bakaláři (distribuce byla zajištěna přímo vedením školy). Respondenti měli na vyplnění 14 dní od obdržení zaslaného odkazu, což bylo přímo zmíněno v průvodním e-mailu i v dotazníku samotném. Celkem bylo získáno 522 vyplněných dotazníků. Počty otázek v dotaznících a míru návratnosti u jednotlivých skupin respondentů shrnuje tabulka 1.

Tabulka 1

Charakteristika dotazníků a míra návratnosti u jednotlivých skupin respondentů

\begin{tabular}{clccc}
\hline Dotazník & Cílová skupina & Počet položek & Počet vyplněných dotazníků & Návratnost \\
\hline 1 & Žáci prvního stupně & 14 & 81 & $69,8 \%$ \\
\hline 2 & Žáci druhého stupně & 14 & 157 & $75,8 \%$ \\
\hline 3 & $\begin{array}{l}\text { Rodiče žáků } \\
\text { prvního stupně }\end{array}$ & 12 & 164 & $61,4 \%$ \\
\hline 4 & $\begin{array}{l}\text { Rodiče žáků druhého } \\
\text { stupně }^{5}\end{array}$ & 11 & 91 & $44,0 \%$ \\
\hline 5 & Učitelé & 18 & 29 & $87,9 \%$ \\
\hline
\end{tabular}

Zdroj: vlastní zpracování.

5 Dotazník pro rodiče žáků z prvního stupně a druhého stupně se lišil pouze v jedné otázce zjištující, zda rodiče žáků z prvního stupně pošlou své děti po 25. 5. 2020 zpět do školy. 


\subsection{Analýza a vyhodnocení dat}

Data byla z Google Forms převedena do tabulkového procesoru MS Excel. Následně byla vyhodnocena metodami popisné statistiky. U otevřených položek bylo použito otevřené kódování a následná kategorizace odpovědí (Flick, 2006; Hendl, 2016). V odpovědích byly nejprve identifikovány obecné koncepty, které byly následně sloučeny do kategorií s podobným zaměřením (Švaříček \& Šed’ová, 2007). Kódování provedly nezávisle na sobě dvě osoby a výsledky byly následně srovnány. $\mathrm{V}$ případě, že mezi kódujícími osobami nebyla shoda, následovala diskuze o vhodnosti užitých kódů. Zároveň byly vybrány ilustrativní výroky, které uvádíme ve výsledkové části, jelikož nejen doplňují prezentované výsledky, ale také identifikují zajímavé oblasti, na které by bylo možné zaměřit následující výzkumy.

\section{$5 \quad$ Výsledky}

Výsledky jsou prezentovány odděleně jako tři dílčí studie a následně jsou v diskuzi porovnány s dalšími dostupnými daty. V první studii jsou prezentována data získaná od žáků (u některých položek jsou rozlišeny odpovědi žáků prvního a druhého stupně), ve druhé studii jsou odpovědi rodičů obou skupin žáků a třetí studie se zaměřuje na učitele. Hned v úvodu bychom rádi předeslali, že se výsledky vztahují k šetření na jedné konkrétní škole, tudíž nemohou být zobecněny. Výzkumníci i škola samotná si uvědomují, že se jedná o závěry pilotní studie, které se ale mohou stát podkladem pro následující systematičtější šetření, které by monitorovalo nejen období bezprostředně po vyhlášení nouzového stavu, ale i období po návratu žáků do škol.

\subsection{Studie 1: žáci}

Výuka v domácím prostředí vyhovovala 43,7 \% dotazovaných žáků. V př́ípadě žáků prvního stupně bylo s distanční výukou spokojeno 42,0 \% dotazovaných, 33,3 \% respondentů tato výuka nevyhovovala a $24,7 \%$ žáků zvolilo možnost, že jim nezáleží na tom, $\mathrm{v}$ jakém prostředí výuka probíhá. Srovnatelné výsledky byly získány u žáků druhého stupně, z nichž 44,6 \% bylo se současnou výukou spokojeno, 21,0 \% tento způsob nevyhovoval a 34,4 \% nepreferovalo jednu formu vzdělávání před druhou. Většina žáků prvního stupně se těšila zpět do školy $(86,4 \%)$, u žáků druhého stupně byla četnost této odpovědi nižší $(68,8 \%)$.

Žáci měli v další položce vybrat $\mathrm{z}$ předem stanovených časových intervalů, kolik času denně tráví nad zadanými úkoly a zároveň se v další položce 
vyjadřovali $\mathrm{k}$ tomu, kolik času by dle jejich názoru měli optimálně nad zadanými úkoly denně trávit (tab. 2).

Tabulka 2

Čas strávený denně nad zadanými úkoly.

\begin{tabular}{|c|c|c|c|c|}
\hline \multirow[b]{2}{*}{60 minut a méně } & \multicolumn{2}{|c|}{$\begin{array}{c}\text { Žáci prvního stupně } \\
(\mathrm{N}=81)\end{array}$} & \multicolumn{2}{|c|}{$\begin{array}{l}\text { Žáci druhého stupně } \\
(\mathrm{N}=157)\end{array}$} \\
\hline & $11 / 10$ & $13,6 \% / 12,3 \%$ & $37 / 32$ & $23,6 \% / 20,4 \%$ \\
\hline 90 minut & $23 / 27$ & $28,4 \% / 33,3 \%$ & 49 / 63 & $31,2 \% / 40,1 \%$ \\
\hline 120 minut & $23 / 30$ & $28,4 \% / 37,0 \%$ & $42 / 45$ & $26,8 \% / 27,8 \%$ \\
\hline více než 120 minut & $24 / 14$ & $29,6 \% / 17,3 \%$ & $29 / 17$ & $18,5 \% / 10,8 \%$ \\
\hline
\end{tabular}

Poznámka: První hodnota je reálný čas trávený nad zadanými úkoly, údaj za lomítkem představuje optimální čas, který by se žáci chtěli zadaným úkolům věnovat

Zdroj: vlastní zpracování.

Za nejobtížnější předmět během domácí výuky označili žáci prvního stupně matematiku $(43,2 \%)$. Téměř čtvrtina žáků této skupiny $(24,7 \%)$ uvedla anglický jazyk a 16,0 \% český jazyk. Na druhém stupni 44,6 \% žáků také označilo za nejtěžší matematiku, následovanou fyzikou $(19,7 \%)$ a českým jazykem $(15,9 \%)$. S obtížností daných předmětů souvisí, kolik úsilí a času žákům zaberou úkoly z jednotlivých předmětů. Žáků ze 4. a 5. tř́́dy jsme se ptali na úkoly z matematiky, českého jazyka, anglického jazyka a vlastivědy (tab. 3). U žáků 6.-9. třídy byl seznam předmětů širší (matematika, český jazyk, anglický jazyk, přírodopis, zeměpis, dějepis a fyzika - viz tab. 4). Záměrně byly vybrány tyto předměty, které mají žáci ve všech zmíněných ročnících.

\section{Tabulka 3}

Náročnost př́pravy na vybrané předměty z pohledu žáků prvního stupně ( $N$ = 81). Zvýrazněna je vždy odpověd's nejvyšší četností

\begin{tabular}{lllll}
\hline & Matematika & Český jazyk & Anglický jazyk & Vlastivěda \\
\hline Hodně & $25,9 \%$ & $9,9 \%$ & $11,1 \%$ & $6,2 \%$ \\
\hline Docela hodně & $13,6 \%$ & $16,0 \%$ & $13,6 \%$ & $9,9 \%$ \\
\hline Přiměřeně & $\mathbf{5 1 , 9} \%$ & $\mathbf{5 8 , 0} \%$ & $\mathbf{5 5 , 6} \%$ & $\mathbf{6 4 , 2} \%$ \\
\hline Docela málo & $7,4 \%$ & $12,3 \%$ & $11,1 \%$ & $14,8 \%$ \\
\hline Málo & $1,2 \%$ & $3,7 \%$ & $8,6 \%$ & $4,9 \%$ \\
\hline
\end{tabular}

Vysvětlivky: MAT - matematika, ČJ - český jazyk, AJ - anglický jazyk, P̌̌ - přírodopis, ZE - zeměpis, D - dějepis, FY - fyzika.

Zdroj: vlastní zpracování. 
Tabulka 4

Náročnost př́pravy na vybrané předměty z pohledu žáků druhého stupně ( $N=157)$. Zvýrazněna je vždy odpověd's nejvyšší četností

\begin{tabular}{llllllll}
\hline & MAT & ČJ & AJ & PŘ & ZE & D & FY \\
\hline Hodně & $15,9 \%$ & $12,1 \%$ & $8,3 \%$ & $4,5 \%$ & $4,5 \%$ & $8,3 \%$ & $21,7 \%$ \\
\hline Docela hodně & $36,3 \%$ & $24,8 \%$ & $14,6 \%$ & $6,4 \%$ & $13,4 \%$ & $19,7 \%$ & $25,5 \%$ \\
\hline Přiměřeně & $\mathbf{4 0 , 1} \%$ & $\mathbf{5 1 , 6} \%$ & $\mathbf{5 2 , 2} \%$ & $\mathbf{5 1 , 0} \%$ & $\mathbf{4 5 , 9} \%$ & $\mathbf{4 0 , 1} \%$ & $\mathbf{3 9 , 5} \%$ \\
\hline Docela málo & $5,1 \%$ & $8,3 \%$ & $20,4 \%$ & $20,4 \%$ & $17,8 \%$ & $21,0 \%$ & $8,9 \%$ \\
\hline Málo & $2,5 \%$ & $3,2 \%$ & $4,5 \%$ & $17,8 \%$ & $18,5 \%$ & $10,8 \%$ & $4,5 \%$ \\
\hline
\end{tabular}

Vysvětlivky: MAT - matematika, ČJ - český jazyk, AJ - anglický jazyk, P̌̌ - př́rodopis, ZE - zeměpis, D - dějepis, FY - fyzika.

Zdroj: vlastní zpracování.

Ve vztahu k náročnosti daných předmětů nás také zajímalo, jakým způsobem žáci řešili zadané úkoly. Polovina (54,3 \%) žáků prvního stupně řešila úkoly samostatně s následnou kontrolou rodičů, dalších 39,5 \% žáků řešilo úkoly s pomocí rodičů. Jen minimum žáků vypracovávalo úkoly zcela samostatně $(3,7 \%)$, popřs s pomocí jiné osoby než rodičů nebo učitele $(2,5 \%)$. Na druhém stupni nejvíce žáků uvedlo, že úkoly řeší zcela samostatně $(33,1 \%)$ nebo s následnou kontrolou rodičů $(28,7$ \%) či učitele $(24,8$ \%). Vyšší procentuální četnost byla zjištěna u možnosti pomoci jiné osoby, např. lektora při doučování nebo sourozence (10,8 \%). Čtyřri žáci $(2,5 \%)$ uvedli, že úkoly řeší s intenzivní pomocí ze strany učitele. Součástí dotazníku pro žáky bylo i sebehodnocení, v němž měli žáci posoudit svůj výkon při domácí výuce. V obou skupinách byla nejvyšší četnost zjištěna u varianty „potřebuji mírnou pomoc od učitele/rodičů " (64,2 \% žáků prvního stupně, 57,3 \% žáků druhého stupně). Pětina (19,8 \%) žáků prvního stupně zvládala úkoly řešit samostatně, 13,6 \% žáků potřebovalo výraznou pomoc ze strany učitele či rodičů a dva žáci $(2,5 \%)$ zvolili možnost, že zadané úkoly nezvládali. Čtvrtina žáků druhého stupně $(27,4 \%)$ dle svého názoru zvládala úkoly samostatně a bez problémů, 12,7 \% žáků potřebovalo výraznou pomoc od rodičů či učitele a jen čtyřri žáci $(2,5 \%)$ uvedli, že úkoly vůbec nezvládali.

Vzhledem k tomu, že některé předměty nebyly distančně vyučovány, se žáci měli vyjádřit k tomu, který předmět jim za dané situace chyběl. Na prvních místech se v odpovědích žáků prvního i druhého stupně umístily výchovy, konkrétně tělesná výchova (19,8 \% žáků prvního stupně; 10,8 \% žáků 
druhého stupně) a výtvarná výchova (13,6 \% žáků prvního stupně; 10,8 \% žáků druhého stupně). Nejčastěji však žáci uvedli, že jim žádný předmět nechybí (54,3 \% žáků prvního stupně, 59,2 \% žáků druhého stupně).

Při distanční výuce se změnil nejen způsob výuky, ale bylo nutné přizpůsobit také způsob hodnocení. Dobře poskytnutá zpětná vazba je při tomto způsobu výuky klíčová, takže jsme se zaměřili i na způsob, jakým zpětnou vazbu žáci od učitelů dostávali. Žáci prvního stupně dostali nejčastěji s odstupem času správné řešení úkolů $(69,1 \%)$ a $21,0 \%$ obdrželo od učitele své řešení s vyznačenými opravami. Osm žáků $(9,9 \%)$ uvedlo, že žádnou zpětnou vazbu od učitele nedostali. I mezi žáky druhého stupně byla nejčastěji uvedena varianta, že učitel zaslal s odstupem času správné řešení $(63,1 \%) ; 28,7$ \% žáků dostalo své řešení s vyznačenými opravami. 13 žáků $(8,3 \%)$ zpětnou vazbu nedostávalo.

Závěrečnou část všech dotazníků tvořila otevřená položka, v níž mohli respondenti uvést, co se jim líbí či nelíbí na distanční výuce. Celkem 73 žáků z prvního stupně a 119 žáků z druhého stupně odpovědělo na tuto položku. Kategorie odpovědí a jejich absolutní četnosti jsou prezentovány v tabulce 5.

Tabulka 5

Četnosti pozitivních a negativních komentářru k distanční výuce - žáci prvního stupně $(N=73)$ a žáci druhého stupně ( $N=119)$. Zvýrazněna je odpověd' s nejvyšší četností ve vztahu k pozitivnímu a negativnímu komentáři

\begin{tabular}{lcc}
\hline Pozitivní komentáře & Žáci prvního stupně & Žáci druhého stupně \\
\hline delší spánek & $\mathbf{2 0}$ & 22 \\
\hline více volného času, možnost dělat si přestávky & 14 & $\mathbf{3 7}$ \\
\hline větší kontakt s rodiči/rodinou & 8 & 6 \\
\hline $\begin{array}{l}\text { možnost přizpůsobení si výuky dle vlastních } \\
\text { potřeb, žádný stres }\end{array}$ & 10 & 29 \\
\hline zábavnější forma, lepší zadané úkoly & 4 & 2 \\
\hline obecná spokojenost & 4 & 5 \\
\hline možnost požádat o pomoc rodiče & 1 & 0 \\
\hline lepší komunikace s učitelem/učiteli & 0 & 2 \\
\hline úkoly nejsou známkované, nepíší se testy & 0 & 1 \\
\hline vyšší míra poskytnuté zpětné vazby & 0 & 1 \\
\hline jiné & 2 & 4 \\
\hline
\end{tabular}




\begin{tabular}{|c|c|c|}
\hline Negativní komentáře & Žáci prvního stupně & Žáci druhého stupně \\
\hline chybějící kontakt se spolužáky & 15 & 17 \\
\hline chybějící výklad učitele & 14 & 22 \\
\hline množství a obtížnost zadaných úkolů & 8 & 24 \\
\hline $\begin{array}{l}\text { spolupráce s rodiči (rozčilují se, chvátají, } \\
\text { nedokáží látku vysvětlit) }\end{array}$ & 3 & 0 \\
\hline chybějící motivace & 2 & 0 \\
\hline nedostatek času & 0 & 1 \\
\hline chybějící zpětná vazba na zadané úkoly & 0 & 3 \\
\hline obecná nespokojenost & 0 & 5 \\
\hline nezáživnost, ve škole je výuka zábavnější & 5 & 3 \\
\hline malý podíl online výuky & 0 & 5 \\
\hline nespokojenost s online výukou & 0 & 2 \\
\hline nevím & 3 & 1 \\
\hline jiné & 4 & 1 \\
\hline
\end{tabular}

Zdroj: vlastní zpracování.

Žáci prvního i druhého stupně ocenili volnější režim, jelikož nemuseli brzy vstávat, mohli si dělat delší přestávky, volit si vlastní tempo zpracování zadaných úkolů a měli větší kontakt se svou rodinou. Na druhou stranu postrádali sociální interakce se spolužáky a chyběl jim i výklad učitele, což lze ilustrovat níže uvedeným výrokem (V1). Druhý (V2) a třetí (V3) prezentovaný výrok ukazují, že žáci rádi trávili čas se svými rodiči, ale neradi se s nimi učili.

V1: Radši bych se učila ve škole - ze začátku to bylo fajn, ale ted' už je to trochu nuda. Chybí mi učitelé i spolužáci.

V2: Nelíbí se mi, že na mě maminka při učení chvátá a že se někdy rozčiluje.

V3: Rodiče neumí tu látku tak dobře vysvětlit, od paní učitelky to pochopím rychleji a lépe.

Žáci na druhém stupni ocenili některé zadané úkoly, které označili za zábavnější.

V4: Přijde mi, že některé úkoly jsou ted' zajímavější a zábavnější. Řešíme praktické úkoly, které si můžeme doma i různě zkoušet. To mě baví! 


\subsection{Studie 2: rodiče}

Zatímco 62,3 \% rodičů žáků z prvního stupně uvedlo, že jim způsob výuky zavedený po 11. březnu 2020 vyhovuje, u respondentů z řad rodičů žáků druhého stupně byly výsledky vyrovnané $(50,5 \%$ respondentů distanční výuka vyhovovala, 49,5\% nikoliv).

Zajištění komunikace učitelů s žáky a jejich rodiči byla jedna z hlavních výzev, před kterou byly školy po vyhlášení nouzového stavu postaveny. Většina rodičů $(89,0 \%$, konkrétně $90,9 \%$ rodičủ žáků prvního stupně a 85,7 \% rodičů žáků druhého stupně) pravidelně s učiteli komunikovala za využití různých prostředků (viz tab. 6).

Tabulka 6

Procentuální četnost zastoupení vybraných způsobů komunikace mezi učiteli a rodiči

\begin{tabular}{lcc}
\hline & $\begin{array}{c}\text { Rodiče žáků z prvního stupně } \\
\mathrm{N}=164\end{array}$ & $\begin{array}{c}\text { Rodiče žáků z druhého stupně } \\
\mathrm{N}=91\end{array}$ \\
\hline Bakaláři & $82,3 \%$ & $84,6 \%$ \\
\hline E-mail & $48,2 \%$ & $47,3 \%$ \\
\hline WhatsApp & $28,0 \%$ & $16,5 \%$ \\
\hline Telefon & $20,1 \%$ & $13,2 \%$ \\
\hline Messenger & $1,2 \%$ & $7,7 \%$ \\
\hline Skype & $0 \%$ & $0 \%$ \\
\hline Jiné & $3,7 \%$ & $4,4 \%$ \\
\hline
\end{tabular}

Zdroj: vlastní zpracování.

Rodiče hodnotili spolupráci s učiteli převážně pozitivně, jelikož 64,6 \% rodičủ žáků prvního stupně ji označilo za výbornou, za spíše dobrou až dobrou ji označilo $33,5 \%$ rodičů z této skupiny a pouze tři rodiče $(3,3 \%)$ se spoluprací nebyli spokojeni. Pozitivně se ke spolupráci stavěli i respondenti z řad rodičů žáků druhého stupně, z nichž 37,4 \% označilo tuto spolupráci za výbornou, dalších 59,4 \% za spíše dobrou až dobrou. Jako špatnou vnímali spolupráci $\mathrm{s}$ učiteli tři rodiče z této skupiny $(3,3 \%)$. Velice pozitivně rodiče žáků prvního stupně reflektovali způsoby, jakými byly žákům zadávány úkoly $(90,2 \%$ pozitivních odpovědí), na druhém stupni byly se zadanými úkoly spokojeny skoro tři čtvrtiny rodičů (73,6 \%). Dle rodičů si své úkoly plnilo 97,6 \% žáků prvního stupně a téměř identický počet $(97,8 \%)$ žáků na druhém stupni. 
Dobu, kterou rodiče trávili přípravou s dětmi, pomocí a kontrolou zadaných úkolů shrnuje tabulka 7 . V tomto případě je zajímavý rozdíl v kategorii $60 \mathrm{mi}$ nut mezi rodiči žáků prvního a druhého stupně, který mohl být způsoben tím, že na prvním stupni byl větší podíl videovýuky, tudíž žáci trávili více času při sledování materiálů a obecně je tempo práce s mladšími žáky nižší, takže zabere řešení úkolů více času.

Tabulka 7

Doba, kterou rodičům zabrala pomoc dětem se zadanými úkoly, popř. jejich následná kontrola

\begin{tabular}{lcc}
\hline & $\begin{array}{c}\text { Rodiče žáků z prvního stupně } \\
\mathrm{N}=164\end{array}$ & $\begin{array}{c}\text { Rodiče žáků z druhého stupně } \\
\mathrm{N}=91\end{array}$ \\
\hline 60 minut a méně & $3,7 \%$ & $23,1 \%$ \\
\hline asi hodinu & $19,5 \%$ & $17,6 \%$ \\
\hline asi 2 hodiny & $48,2 \%$ & $30,8 \%$ \\
\hline 3 hodiny a více & $29,3 \%$ & $28,6 \%$ \\
\hline
\end{tabular}

Zdroj: vlastní zpracování.

Na otevřenou položku zjišt'ující pozitiva a negativa distanční výuky z pohledu rodičů žáků odpovědělo celkem 119 rodičủ žáků z prvního stupně a 63 rodičů žáků z druhého stupně (tab. 8).

Tabulka 8

Četnosti pozitivních a negativních komentářo $k$ distanční výuce - rodiče žáků prvního stupně $(N=119)$ a rodiče žáků druhého stupně $(N=63)$. Zvýrazněna je odpověd's nejvyšši četností ve vztahu k pozitivnímu a negativnímu komentáři

\begin{tabular}{lcc}
\hline Pozitivní komentáře & $\begin{array}{c}\text { Rodiče žáků } \\
\text { prvního stupně }\end{array}$ & $\begin{array}{c}\text { Rodiče žáků } \\
\text { druhého stupně }\end{array}$ \\
\hline $\begin{array}{l}\text { možnost přizpůsobení si výuky dle vlastních potřeb, } \\
\text { méně stresu }\end{array}$ & $\mathbf{2 1}$ & $\mathbf{1 0}$ \\
\hline osobní př́stup konkrétního učitele/učitelů & 13 & 5 \\
\hline materiály vytvářené učitelem/učiteli & 12 & 2 \\
\hline větší kontakt s vlastním dítětem/dětmi & 10 & 2 \\
\hline rozvoj samostatnosti dítěte/dětí & 7 & 8 \\
\hline lepší komunikace s učiteli & 4 & 4 \\
\hline celková spokojenost & 3 & 8 \\
\hline
\end{tabular}




\begin{tabular}{|c|c|c|}
\hline Pozitivní komentáře & $\begin{array}{c}\text { Rodiče žáků } \\
\text { prvního stupně }\end{array}$ & $\begin{array}{c}\text { Rodiče žáků } \\
\text { druhého stupně }\end{array}$ \\
\hline využívání moderních technologií & 2 & 0 \\
\hline výborná př́íprava a organizace ze strany školy/učitelů & 1 & 0 \\
\hline jiné & 3 & 2 \\
\hline Negativní komentáře & $\begin{array}{c}\text { Rodiče žáků } \\
\text { prvního stupně }\end{array}$ & $\begin{array}{c}\text { Rodiče žáků } \\
\text { druhého stupně }\end{array}$ \\
\hline $\begin{array}{l}\text { nedostatek času věnovat se zadaným úkolům } \\
\text { (pracovní a další povinnosti) }\end{array}$ & 21 & 6 \\
\hline chybějící sociální interakce se spolužáky i s učiteli & 16 & 4 \\
\hline nízká motivace dětí & 15 & 2 \\
\hline $\begin{array}{l}\text { náročné z hlediska znalostí rodičů a jejich } \\
\text { pedagogických dovedností }\end{array}$ & 14 & 7 \\
\hline malý podíl online výuky & 13 & 5 \\
\hline nejednotně zadávané úkoly & 10 & 8 \\
\hline množství zadaných úkolů & 8 & 9 \\
\hline chybějící výklad učitele & 7 & 12 \\
\hline $\begin{array}{l}\text { chybějící průběžná kontrola či zpětná vazba na zadané } \\
\text { úkoly }\end{array}$ & 2 & 3 \\
\hline nevhodný osobní přístup konkrétního učitele/učitelů & 0 & 2 \\
\hline problémy spojené s elektronickou komunikací & 0 & 2 \\
\hline $\begin{array}{l}\text { chybějící doplňkové materiály, které by bylo možné } \\
\text { využít }\end{array}$ & 0 & 2 \\
\hline jiné & 7 & 9 \\
\hline nevím & 3 & 1 \\
\hline
\end{tabular}

Zdroj: vlastní zpracování.

Rodiče žáků prvního stupně často vyzdvihli osobní přístup některých učitelů a materiály, které učitelé pro žáky vytvářeli. Ocenili i časovou náročnost vytváření výukových materiálů.

V5: Zadávání úkolů paní učitelkou X (pozn. anonymizováno) je úplně skvělé. Prezentace jsou srozumitelné a videa zábavná. Zvládáme to dobře. Negativa nevidím v tuto chvíli žádná. Musí za tím vším být neskutečná hromada práce!

Za největší pozitivum označili rodiče žáků druhého stupně možnost přizpůsobovat si výuku dle svých momentálních možností, zejména časových. V souvislosti s tím dodávali, že se děti alespoň učí zodpovědnosti za vlastní učení a rozvíjí se u nich samostatnost. Ocenili také intenzivnější kontakt 
s vlastním dítětem, resp. dětmi, a lepší porozumění jejich učení a potřebám, včetně uvědomění si některých jejich problémů s učením.

V6: Dcera je více samostatná, není pod tlakem vyučovací hodiny a úprava a zpracování jejích úkolů je mnohem estetičtější. Dceři systém vyhovuje, ale samozřejmě upřednostňuje předměty, které ji baví, a odsouvá ty neatraktivní, ale plní všechny povinnosti vzorně.

Jako největší úskalí distanční výuky označili rodiče žáků prvního stupně časové dispozice, zejména ve vztahu k vlastním pracovním povinnostem. Často také zmiňovali nutnost si samostatně danou problematiku nastudovat, protože si ji již nepamatují z doby své školní docházky, vlastní nedostatečné pedagogické dovednosti a obecně chybějící výklad učitele.

V7: Při náročném zaměstnání nemám prostor ani sílu věnovat se večer ještě tomu, co všechno měly děti udělat, kontrolovat, nutit k úkolům, poradit, něco s nimi probrat. Často už látku ani sama neznám, takže bych potřebovala všechno předem sama nastudovat, abych věděla, co po nich mám chtít. Při více dětech je to o to náročnější.

V8: Neumíme látku vysvětlit a mladší dcera má poruchu soustředění a dyslexii, takže je u ní výuka obtížnější, protože potřebuje odborný výklad pedagoga. Oba jsme s manželkou v zaměstnání, takže přes den nejsme doma. I když se snažíme, tak si myslíme, že rodiče nemohou dětem nahradit školu a kolektiv.

Dále rodiče kritizovali množství zadaných úkolů a nejednotnost v jejich zadávání. Tímto je myšleno, že každý z učitelů používal jinou platformu, kam úkoly nahrával, tudíž je rodiče, resp. žáci, museli průběžně kontrolovat.

V9: Úkolů už je řada a někdy máme problém si to uspořádat, vyznat se v tom a na nic nezapomenout. Chápu obě strany, učitele, kteří potřebují probírat látku, ale i děti, které se nikdy nesetkaly s tím, že by měly ve studiu fungovat samy. Nedivím se jim, že se v tom neorientují a je to i pro ně náročné, dokonce samy říkají, že chtějí jít raději do školy.

\subsection{Studie 3: učitelé}

Necelé polovině $(48,3$ \%) oslovených učitelů vyhovoval distanční způsob výuky. Ze šetření vyplynulo, že třídní učitelé navázali komunikaci se všemi žáky. 18 učitelů $(62,1 \%)$ uvedlo, že maximálně tři žáci s nimi následně při výuce 
nespolupracovali (tzn. nereagovali na zasílané zprávy, neodevzdávali úkoly, nekonzultovali apod.). Sedm učitelů $(24,1 \%)$ mělo problém se spoluprací u 4-10 žáků. Více nespolupracujících žáků uvedli další čtyři učitelé (jeden 11-15 dětí a tři 16 až 20 dětí). Zdá se, že nespolupracující žáci bojkotovali činnost u konkrétních předmětů, popř. učitelů, kteří tyto předměty vyučují. Ve spolupráci s rodiči nespatřovali učitelé výraznější problémy, jelikož 96,6 \% dotazovaných uvedlo, že s nimi rodiče bez problémů spolupracovali a komunikovali. Jedenáct učitelů $(37,9 \%)$ tuto spolupráci označilo za výbornou, zbývajících 62,1 \% učitelů ji považovalo za dobrou až spíše dobrou. Způsoby komunikace učitelů s žáky a jejich rodiči shrnuje tabulka 9.

Tabulka 9

Způsoby komunikace učitelů s žáky a jejich rodiči $(N=29)$

\begin{tabular}{lcccc}
\hline & \multicolumn{2}{c}{ Komunikace s žáky } & \multicolumn{2}{c}{ Komunikace s rodiči } \\
\hline Bakaláři & 26 & $89,7 \%$ & 25 & $86,2 \%$ \\
\hline E-mail & 25 & $86,2 \%$ & 26 & $89,7 \%$ \\
\hline Telefon & 11 & $37,9 \%$ & 15 & $51,7 \%$ \\
\hline WhatsApp & 11 & $37,9 \%$ & 11 & $37,9 \%$ \\
\hline Messenger & 5 & $17,2 \%$ & 2 & $6,9 \%$ \\
\hline Jiné & 3 & $10,3 \%$ & 2 & $6,9 \%$ \\
\hline Skype & 1 & $3,4 \%$ & 0 & $0,0 \%$ \\
\hline
\end{tabular}

Zdroj: vlastní zpracování.

Organizace výuky při distanční výuce je pro učitele obecně časově náročnější, protože si musí připravit materiály, které žákům posílají, a následně opravit úkoly, které žákům zadali. Př́prava se u učitelů nejčastěji pohybovala mezi dvěma $(34,5 \%)$ až třemi $(31,0 \%)$ hodinami. Jeden z učitelů uvedl, že mu přípravy trvají více než 5 hodin. $V$ tomto případě se jednalo o učitele první třídy, který natáčel autorská videa pro své žáky (např. pohádky k jednotlivým písmenům abecedy). S př́ípravou výuky souvisí i využívání různých zdrojů a materiálů (tab. 10). 


\section{Tabulka 10}

Materiály, které učitelé využívali při distanční výuce

\begin{tabular}{lcc}
\hline Odkazy na učebnici a pracovní sešit & 28 & $96,6 \%$ \\
\hline Vlastní pracovní listy & 24 & $82,8 \%$ \\
\hline Odkazy na www stránky & 23 & $79,3 \%$ \\
\hline Digitální učební materiály (tzv. DUMy) & 21 & $72,4 \%$ \\
\hline Vlastní prezentace & 14 & $48,3 \%$ \\
\hline Výukové programy & 10 & $34,5 \%$ \\
\hline Neplacené aplikace & 10 & $34,5 \%$ \\
\hline Jiné & 8 & $27,6 \%$ \\
\hline Vlastní videa & 4 & $13,8 \%$ \\
\hline
\end{tabular}

Zdroj: vlastní zpracování.

Opravám zadaných úkolů se učitelé věnovali kratší dobu, jelikož nejvíce respondentů $(41,4 \%)$ uvedlo možnost, že jim opravy zabraly méně než hodinu. Polovina učitelů $(55,2 \%)$ uvedla, že posílala žákům zpět opravené úkoly nebo s odstupem času zasílali správné řešení. 48,3 \% učitelů s žáky jejich postup konzultovali, tudíž měli žáci možnost zjistit, kde přesně udělali chybu, a dozvěděli se také, jak odstranit případné nedostatky. Pět učitelů $(17,2 \%)$ uvedlo, že žákům žádnou zpětnou vazbu neposkytovali.

I učitelé, stejně jako respondenti výše uvedených dotazníků, se vyjadřovali k tomu, jaká pozitiva či negativa spatřují u distanční výuky. Na tuto položku uvedlo odpověd' 26 učitelů, jejich odpovědi jsou shrnuty v tabulce 11.

Tabulka 11

Četnosti pozitivních a negativních komentářo $k$ distanční výuce - učitelé ( $N$ = 63). Zvýrazněna je odpověd's nejvyšší četností ve vztahu $k$ pozitivnímu a negativnímu komentáři

\begin{tabular}{ll}
\hline Pozitivní komentáře & $\mathbf{7}$ \\
\hline práce v klidnějším prostředí (delší spánek, méně stresu) & 4 \\
\hline navázání lepších interakcí s rodiči i žáky, více jsme se poznali & 2 \\
\hline volnější časový rozvrh, vlastní organizace harmonogramu & 2 \\
\hline videohovory se žáky & 2 \\
\hline seznámení se s alternativními zdroji k výuce a práce s nimi & 1 \\
\hline zlepšení se v IT dovednostech & 1 \\
\hline jiné
\end{tabular}




\begin{tabular}{lc}
\hline Negativní komentáře & $\mathbf{1 5}$ \\
\hline malá interakce se žáky a kontakt mezi žáky navzájem & 13 \\
\hline chybějící okamžitá zpětná vazba od žáků, zda látce rozumí & 5 \\
\hline malý kontakt s kolegy & 1 \\
\hline nedostatek adekvátních výukových materiálů & 1 \\
\hline nedostatečná znalost IT & 2 \\
\hline náročnost (př́prava materiálů, výroba vlastních videonahrávek apod.) & 2 \\
\hline stereotyp činností, nemožnost využívat některé vyučovací metody a formy & 1 \\
\hline pasivita některých dětí (bez výrazných možností, jak tuto situaci změnit)
\end{tabular}

Zdroj: vlastní zpracování.

Učitelé pozitivně hodnotili navázání lepších interakcí se žáky a uvedli, že paradoxně tím, že se nemohou vídat, se při řešení této situace jejich vztahy utužily. Negativní komentáře učitelů se věnovaly nedostatečné zpětné vazbě od žáků, tzn. učitelé měli omezené možnosti, jak si ověřit, že žáci látce opravdu rozumí (při online výuce nelze reagovat na potřeby úplně všech žáků apod.). Jako významné negativum hodnotili také chybějící sociální interakce, nejen žáků s učiteli, ale zejména mezi žáky navzájem.

V10: Líbí se mi snaha dětí a jejich spolupráce se mnou i mezi sebou. Oceňuji touhu zvládnout a překonat překážky ve výuce. Baví mě také komunikace s dětmi o současné situaci, při které si spoustu věcí můžeme vysvětlit.

V11: Z mého pohledu je distanční výuka podstatně náročnější než ta prezenční, nebot' vyžaduje intenzivní telefonické či písemné reakce každému žákovi zvlášt', př́ípadně i jeho rodičům. Některé děti by potřebovaly každodenní osobní kontakt, z komunikace s nimi je patrné, že jim chybí spolužáci, ale i škola jako taková.

Jedna z učitelek poměrně sebekriticky zhodnotila své problémy s digitálními technologiemi. Pozitivní však na tomto komentáři je fakt, že přestože tato učitelka dříve technologie nevyužívala a nebyla v jejich užívání zdatná, tak si jejich užívání snažila osvojit, aby zajistila výuku v potřebném rozsahu.

V12: Nelíbí se mi nedostatek prostředků pro online výuku na mé straně, ale i na straně dětí. Úskalím je také moje zcela nedostatečná digitální gramotnost, kterou se za velkých porodních bolestí snažím rozvíjet za pochodu a v době, kdy na to nemám dostatek času. 


\section{Diskuze a závěr}

Hlavním cílem provedeného šetření bylo postihnout okamžitou reakci konkrétní školy na opatření spojená s neočekávanou situací na jaře 2020. Z tohoto důvodu je nutné nahlížet na prezentované výsledky jako na rychlou sondu, jejíž výsledky měly identifikovat základní problémové oblasti spojené s náhle zavedenou distanční výukou. Celkově se šetření zaměřilo zejména na technické zajištění výuky, způsoby komunikace mezi aktéry vzdělávacího procesu (učitelé, žáci a jejich rodiče), využívání zdrojů a práci s nimi a časovou dotaci spojenou s distanční výukou.

Z hlediska technického zajištění distanční výuky vyplývá z našeho šetření, že na dané škole se většina žáků do distanční výuky zapojila, což odpovídá závěrům šetření České školní inspekce (ČŠI, 2020) a Broma s kolektivem (2020). ČŠI (2020) upozorňovala na přibližně 9500 žáků základních a středních škol, u kterých nebyla distanční výuka nijak realizována. Tato situace na námi sledované škole nenastala, jelikož všichni žáci se školou komunikovali, pouze někteří jedinci neplnili zadané úkoly. Příčinou nebyla technická nevybavenost, škola nabídla rodičům zapůjčení potřebného vybavení (pěti žákủm byly zapůjčeny notebooky od sponzorů) a také zjištovala, zda mají žáci k dispozici internetové připojení. Nikdo z rodičů si v rámci dotazování ze strany školy nestěžoval na absenci internetového připojení. Tyto dva zmíněné faktory však uváděla ČŠI (2020) jako hlavní př́čciny selhání online komunikace žáků se školou, potažmo učiteli. Např́klad Brom s kolektivem (2020) zdůraznili problém se sdílením počítače, který potřebují rodiče pro svůj home office, ale zároveň i jejich dítě pro výuku (Brom et al., 2020). V našem př́ípadě však rodiče spíše zmiňovali chybějící zařízení pro tisk či skenování materiálů a softwarovou nevybavenost či neznalost komunikačních platforem a aplikací. Při analýze překážek $v$ distanční výuce je mimo jiné nutné rozlišovat konkrétní způsoby realizace distanční výuky. Komunikace byla realizována prostřednictvím portálu Bakaláři a e-mailové korespondence, což koresponduje s výsledky České školní inspekce, jelikož na více než polovině českých škol byla používána školní platforma všemi učiteli (ČŠI, 2020). Na druhou stranu pro zasílání úkolů poté učitelé využívali rozmanité aplikace či prostředí, což v některých případech působilo žákům a rodičům obtíže, jelikož si museli průběžně kontrolovat tyto aplikace či prostředí a dohledávat zaslané informace. Tato skutečnost byla způsobena zejména náhlostí dané situace 
a nutnosti bezprostřední reakce a jeví se jako jeden ze zásadních problémů realizace distančního vzdělávání (nejen) na této škole.

Vzhledem k využívání zdrojů a práci s nimi při distanční výuce bylo zjištěno, že námi dotazovaní učitelé pracovali s učebnicemi, pracovními sešity, materiály z programu České televize UčíTelka nebo si vytvářeli vlastní listy či využívali digitální učební materiály (tzv. DUMy), což koresponduje i s průzkumy České školní inspekce (ČŠI, 2020). Ve vztahu k digitálním učebním materiálům uvedlo v naší studii devět učitelů (z 29 dotazovaných), že tyto materiály sice využívají, ale musí si je vždy upravit či opravit. Tím naráželi na otázku relevance volně dostupných DUMů, které jsou v některých př́ípadech chybně zpracované z hlediska didaktického, ale i obsahového, tudíž je potřeba jejich zpracování před zařazením do výuky kriticky posoudit. Poměrně kriticky se učitelé vyjádřili i k některým materiálům, na které bylo odkazováno z portálu \#NaDálku. Lze říci, že se ukázala metodická nepřipravenost regionálního školství na využívání digitálních technologií i distanční formy výuky. Samozřejmě, daná situace nastala ze dne na den, ale v době, kdy se klade důraz na digitální gramotnost a digitalizaci, by měl být přechod k této formě výuky plynulejší (napřr. využívat jednotný komunikační kanál, mít připravené vybrané kvalitní materiály v digitální podobě, ve větší míře užívat cloudová uložiště apod.). Příkladem dobré praxe může být již výše zmíněné Estonsko a jeho program pro digitalizaci učebních materiálů (viz iniciativa Education Nation).

Z výsledků našeho šetření je patrné, že žáci a jejich rodiče považovali celkový čas věnovaný přípravě a řešení úkolů zadaných při distanční výuce za př́liš velký, což však odporuje výsledků ve vztahu času stráveného př́pravou a řešením úkolů spojených $s$ jednotlivými vyučovacími předměty, v nichž žáci považovali strávený čas za přiměřený. Rodiče dotazovaní ve studii Broma a kolektivu (2020) navrhovali omezení šíre a rozsahu učiva ve smyslu zachování výuky pouze hlavních předmětů (český jazyk, matematika, anglický jazyk). Tento přístup zvolila i námi sledovaná škola, kde se výuka soustředila převážně na profilové předměty. Žáci uvedli, že při řešení zadaných úkolů potřebují mírnou pomoc ze strany rodičů či učitele, popř́padě následnou kontrolu, pokud úkol zpracovávali samostatně. Tento závěr potvrzuje velmi významnou roli zpětné vazby, kterou žák na svou práci od učitele obdrží. Rodiče často nemají dostatečné pedagogické dovednosti ve smyslu znalosti didaktických postupů a zásad, ale i vědomostí spojených s probíraným 
učivem, tudíž může být problematické danou látku svému dítěti vysvětlit (Brom et al., 2020). Zpětná vazba od učitele představuje nejen souhrn toho, čeho žák dosáhl, ale měla by také žákovi nastínit jeho další kroky v procesu učení. Naši respondenti z řad rodičủ žáků i učitelů uváděli, stejně jako rodiče ve výše zmíněné studii, že vysvětlení nového učiva jim zabírá více času než kontrola zadaných úkolů. Na výsledky dotazníkového šetření škola reagovala zvýšením podílu online výuky prostřednictvím MS Teams, což vedlo také $\mathrm{k}$ určitému sjednocení zadávaných úkolů, které bylo možné zadávat právě pomocí tohoto prostředí. Vedení školy k práci s MS Teams uspořádalo několik webinářủ a prostřednictvím videovýuky byla následně zprostředkována výuka nového učiva v profilových předmětech. Ze šetření jednoznačně vyplynulo, že rodiče vnímali objem času, který byl od nich vyžadován pro součinnost $\mathrm{v}$ rámci distanční výuky, jako velmi zatěžující bez ohledu na to, zda se jednalo o výklad nové látky či pomoc a kontrolu řešení zadaných úkolů. Jako problém lze označit nutnost vlastní přípravy rodičů na distanční výuku.

Za pozitivní efekt distanční výuky lze obecně považovat seznámení se s novými způsoby online výuky a rozvinutí dovedností učitelů, žáků i rodičů spojených s digitální gramotností. Ředitelé škol uvedli, že tyto nově získané dovednosti lze využít i pro zkvalitnění běžné prezenční výuky (ČŠI, 2020), popř́ípadě získané zkušenosti umožní pružnější reakci všech aktérů výchovně-vzdělávacího procesu v případě, že by se daná situace opět opakovala.

Jak jsme již předeslali v textu prríspěvku, cílem naší studie bylo identifikovat možné další směry, kterými by se mohl ubírat následující pedagogický výzkum, zejména 1) sledovat, jakým způsobem mají školy zpracovanou metodickou podporu jednotlivých aktérů vzdělávacího procesu pro případné další zavedení distanční výuky (zejména způsob podpory rodičů žáků); 2) analyzovat, jakým způsobem vybrané školy přistupují k digitalizaci vlastních výukových materiálů v kontextu běžné výuky; 3 ) zkoumat, zda měla distanční výuka dopad na digitální gramotnost učitelů a žáků a do jaké míry si osvojili nové metody práce s digitálními technologiemi, včetně trvalosti nově osvojených dovedností; 4) posoudit obsahovou a didaktickou kvalitu materiálů, které slouží jako podpora pro distanční výuku; 5) sledovat, jakým způsobem reagovali žáci s různými učebními styly na distanční výuku. Jako vhodný směr dalšího výzkumu se jeví sledování dopadu distanční výuky na úroveň znalostí a dovedností žáků, avšak v tomto případě jsou pro řešené období problémem chybějící relevantní data, která by prezentovala výchozí situaci před vyhlášením nouzového stavu a zavedením distanční výuky. 
Ve vztahu k naší studii také můžeme identifikovat určitá metodologická omezení či nedostatky, které byly způsobeny zejména snahou o rychlou realizaci sběru dat, protože škola potřebovala výsledky včas, aby na ně mohla adekvátně reagovat. Např́íklad u položek věnující se času, který žáci tráví při distanční výuce, by bylo vhodnější nastavit časové intervaly adekvátně k vyučovacím hodinám, což by usnadnilo srovnání s prezenční formou výuky. Zároveň se ztotožňujeme s názorem Broma a kolektivu (2020), kteří zdůrazňují, že účast v šetření byla dobrovolná, tudíž se do něj často zapojili rodiče, kteří mají zájem o vzdělávání svých dětí, resp. žáci, kteří s učitelem a školou běžně spolupracují. Nelze tedy mluvit o kompletním vzorku žáků a rodičů a dané výsledky není možné zobecnit pro celou populaci. Souhlasíme také $\mathrm{s}$ tvrzením, že se škola nemůže $\mathrm{v}$ žádném případě zavděčit všem, zejména s ohledem na někdy specifické potřeby žáků i rodičů.

\section{Literatura}

Bednaříková, I. (2013). Možnosti a limity e-learningu ve středoškolském vzdělávání. e-Pedagogium, 13(3), 119-128.

Brom, C., Lukavský, J., Greger, D., Hannemann, T., Straková, J., \& Švaříček, R. (2020, duben). Mandatory home education during the COVID-19 lockdown in the Czech Republic: A rapid survey of $1^{\text {st }}-9^{\text {th }}$ graders' parents. Frontiers in Education, 5, 103.

Česká televize (2020). Česká televize spustí vyučování prostrednictvím obrazovky. Pořadem UčíTelka reaguje na zavření škol. Dostupné z https://ct24.ceskatelevize.cz/ domaci/3062122-ceska-televize-v-pondeli-spusti-vysilani-pro-skolaky-porad-ucitelkaokamzite-reaguje

ČŠI (2020). Vzdělávání na dálku v základních a středních školách. Tematická zpráva. Praha: Česká školní inspekce. Dostupné z https://www.csicr.cz/Csicr/media/Prilohy/PDF_ el._publikace/Tematick\%c3\%a9\%20zpr\%c3\%a1vy/Vzdelavani-na-dalku-v-ZS-a-SSTematicka-zprava.pdf

Eger, L. (2004). E-learning, evaluace e-learningu + př́padová studie z projektu Comenius. Plzeň: Západočeská univerzita v Plzni.

Flick, U. (2006). An introduction to qualitative research. Thousand Oaks: Sage.

Gavora, P. (2010). Úvod do pedagogického výzkumu. Brno: Paido.

Hale, T., Webster, S., Petherick, A., Phillips, T., \& Kira, B. (2020). Data from: Oxford COVID-19 Government Response Tracker, Blavatnik School of Government. Dostupné z https:// covidtracker.bsg.ox.ac.uk/

Hendl, J. (2016). Kvalitativní výzkum: základní metody a aplikace. Praha: Portál.

Hesson, M., \& Shad, K. F. (2007). A student-centered learning model. American Journal of Applied Sciences, 4(9), 628-636.

Cheng, X. (2020). Challenges of "School's Out, But Class's On" to school education. Science Insights Education Frontiers, 5(2), 501-516. 
Chinazzi, M., Davis, J. T., Ajelli, M., Gioannini, C., Litvinova, M., Merler, S.,... Viboud, C. (2020). The effect of travel restrictions on the spread of the 2019 novel coronavirus (COVID-19) outbreak. Science, 368(6489), 395-400.

Kalhous, Z., \& Obst, O. (2002). Školní didaktika. Praha: Portál.

Kennedy, K., \& Ferdig, R. E. (2018). Handbook of research of K12 online and blended learning. Pittsburgh: Carnegie Mellon University, ETC Press.

Kraemer, M. U., Yang, C. H., Gutierrez, B., Wu, C. H., Klein, B., Pigott, D. M.,... Brownstein, J. S. (2020). The effect of human mobility and control measures on the COVID-19 epidemic in China. Science, 368(6490), 493-497.

Kwok, K. O., Li, K. K., Chan, H. H., Yi, Y. Y., Tang, A., Wei, W. I., Wong, Y. S. (2020). Community responses during early phase of COVID-19 epidemic, Hong Kong. Emerging Infectious Diseases, 26(7), 1575-1579.

Maier, P., Barmett, L., Warren, A., \& Brunner, D. (1998). Using technology in teaching and learning. London: Kogan Page.

Ministry of Education of the People's Republic of China. (2020). Notice on "School's Out, But Class's On" work arrangements during the postponed period. Dostupné z http://www.moe. gov.cn

MŠMT (2020a). Doporučené postupy pro školy v období vzdělávání na dálku. Dostupné z https:// www.msmt.cz/doporucene-postupy-pro-skoly-v-obdobi-vzdelavani-na-dalku

MŠMT (2020b). Vzdělávání \#NaDálku. Dostupné z https://nadalku.msmt.cz/cs

MZČR (2020a). Onemocnění aktuálně. COVID-19: Přehled aktuální situace v ČR. Dostupné z https://onemocneni-aktualne.mzcr.cz/covid-19

MZČR (2020b). Mimořádné opatření, č. j. MZDR 10676/2020-1/MIN/KAN, 10. 3. 2020. Praha: Ministerstvo zdravotnictví České republiky.

Oreopoulos, P. (2006). Estimating average and local average treatment effects of education when compulsory schooling laws really matter. American Economic Review, 96(1), 152-175.

Průcha, J., \& Míka, J. (2000). Distanční studium v otázkách. Průvodce studujících a zájemců o studium. Praha: Národní centrum distančního vzdělávání - Centrum pro studium vysokého školství.

Simonson, M., Zvacek, S. M., \& Smaldino, S. (2019). Teaching and learning at a distance: Foundations of distance education. Charlotte: Information Age Publishing.

Sintema, E. J. (2020). Effect of COVID-19 on the performance of grade 12 students: Implications for STEM education. EURASIA Journal of Mathematics, Science and Technology Education, 16(7).

Švaříček, R., \& Šed’ová, K., et al. (2007). Kvalitativní výzkum v pedagogických vědách. Praha: Portál.

UNESCO (2020a). COVID-19 educational disruption and response. Paris: UNESCO. Dostupné z https://en.unesco.org/covid19/educationresponse

UNESCO (2020b). Distance learning solutions. Dostupné z https://en.unesco.org/covid19/ educationresponse/solutions

Uscher-Pines, L., Schwartz, H. L., Ahmed, F., et al. (2018). School practices to promote social distancing in K-12 schools: Review of influenza pandemic policies and practices. BMC Public Health, 18(1), 406.

Viner, R. M., Russell, S., Croker, H., Packer, J., Ward, J., Stansfield, C., Mytton, O., \& Booy, R. (2020). School closure and management practices during coronavirus outbreaks including 
COVID-19: A rapid narrative systematic review. The Lancet Child \& Adolescent Health, 4(5), 397-404.

Vláda ČR (2020). Usnesení vlády České republiky ze dne 12. března 2020, č. 194. Dostupné $\mathrm{z}$ https://www.vlada.cz/assets/media-centrum/aktualne/Usneseni-vlady-k-vyhlaseninouzoveho-stavu.pdf

Všetulová, M., Nocar, D., Urbášková, L., \& Dvořáková, M. (2007). Př́ručka pro tutora. Olomouc: Akademie distančního vzdělávání.

WHO (2020). Director-General's opening remarks at the Mission briefing on COVID-19 - 12 March 2020. Geneva: World Health Organisation (WHO). Dostupné z https://www.who.int/dg/ speeches/detail/who-director-general-s-opening-remarks-at-the-mission-briefing-oncovid-19---12-march-2020

Wu, Z., \& McGoogan, J. M. (2020). Characteristics of and important lessons from the coronavirus disease 2019 (COVID-19) outbreak in China: Summary of a report of 72314 cases from the Chinese Center for Disease Control and Prevention. JAMA, 323(13),1239-1242.

Xie, Z., \& Yang, J. (2020). Autonomous learning of elementary students at home during the COVID-19 epidemic: A case study of the second elementary school in Daxie, Ningbo, Zhejiang Province, China. Best Evidence of Chinese Education, 4(2), 535-541.

Yen, M. Y., Chiu, A. W., \& Schwartz, J., et al. (2014). From SARS in 2003 to H1N1 in 2009: Lessons learned from Taiwan in preparation for the next pandemic. Journal of Hospital Infection, 87(4), 185-193.

Zhou, L. J., \& Li, C. G. (2020) Can student self-directed learning improve their academic performance? Experimental evidence from the instruction of protocol-guided learning in China's elementary and middle schools. Science Insights Education Frontiers, 5(1), 469-480.

Zlámalová, H. (2007). Distanční vzdělávání - včera, dnes a zítra. e-Pedagogium, 7(3), 29-44.

Zu, Z. Y., Jiang, M. D., Xu, P. P., Chen, W., Ni, Q. Q., Lu, G. M., \& Zhang, L. J. (2020). Coronavirus disease 2019 (COVID-19): A perspective from China. Radiology (v tisku).

\section{Autoři}

Mgr. Lukáš Rokos, Ph.D., Jihočeská univerzita v Českých Budějovicích, Pedagogická fakulta, Katedra biologie, Jeronýmova 10,371 15 České Budějovice, e-mail: Irokos@pf.jcu.cz

Mgr. Michal Vančura, Ph.D., Jihočeská univerzita v Českých Budějovicích, Pedagogická fakulta, Katedra geografie, Jeronýmova 10, 37115 České Budějovice, e-mail: vancura@pf.jcu.cz

\section{Distance learning during the coronavirus pandemic from the teachers', pupils' and their parents' point of view}

Abstract: The aim of this study was to find out the views of teachers, pupils and their parents in relation to distance teaching established due to coronavirus pandemic. The questionnaire survey took place at a selected elementary school. In total 
522 questionnaires were collected. The way of communication, the time necessary to prepare and control tasks as well as personal views on distance learning of all groups of respondents were examined. It was found that all pupils were involved in the distance education at selected school thanks to technical support. However, the problem is the level of their involvement and the overall activity in distance learning. Teachers used different platforms and applications to communicate with pupils and parents and this seems to be inappropriate for longer-term distance learning solutions. The absence of methodological support for parents of pupils clearly poses a further risk for the successful implementation of distance learning. Although the situation changed suddenly and the school started distance education without significant problems this study enables to identify areas which further pedagogical research could be focused on.

Keywords: covid-19, distance education, home education 


\section{Přílohy}

Dotazníky byly respondentům distribuovány ve virtuální podobě prostřednictvím Google Forms (ve zde prezentované verzi vznikly pouze pro účely této př́lohy). Dotazníky pro žáky prvního a druhého stupně se lišily pouze $\mathrm{v}$ detailech (viz poznámky v textu příspěvku).

\section{Př́loha 1: Dotazník pro žáky druhého stupně}

\section{Pohlaví}
A) chlapec
B) dívka

\section{Třída}

\begin{tabular}{llll}
\hline 6. & 7. & 8. & 9.
\end{tabular}

3. Vyhovuje Ti současný způsob výuky na dálku (od 11. 3. 2020)?
A) ano
B) ne
C) je mi to jedno

4. Nad zadanými úkoly strávím každý den přibližně...

\begin{tabular}{ll}
\hline A) 60 minut a méně & C) 120 minut \\
\hline B) 90 minut & D) více než 120 minut \\
\hline
\end{tabular}

5. Jak dlouho by se podle Tvého názoru měl žák při výuce v domácím prostředí denně věnovat zadaným úkolům?
A) 60 minut a méně
C) 120 minut
B) 90 minut
D) více než 120 minut

6. Kolik času Ti denně zabere řešení úkolů z...

\begin{tabular}{|c|c|c|c|}
\hline & hodně & docela hodně & docela málo málo \\
\hline \multicolumn{4}{|l|}{ A) matematiky } \\
\hline \multicolumn{4}{|c|}{ B) českého jazyka } \\
\hline \multicolumn{4}{|c|}{ C) anglického jazyka } \\
\hline D) prŕírodopisu & & & \\
\hline
\end{tabular}


E) zeměpisu

F) dějepisu

G) fyziky

\section{Zadané úkoly řešíš převážně...}

\begin{tabular}{ll}
\hline A) úplně samostatně & D) s pomocí učitele \\
\hline B) samostatně s následnou kontrolou rodičù & $\begin{array}{l}\text { E) s pomocí jiné osoby než rodičů nebo } \\
\text { učitele (např. doučování, lektor) }\end{array}$ \\
\hline C) s pomocí rodičů & F) jiný způsob: \\
\hline
\end{tabular}

8. Jaký předmět je pro Tebe při domácí výuce nejobtížnější?

\begin{tabular}{ll}
\hline A) matematika & E) zeměpis \\
\hline B) český jazyk & F) dějepis \\
\hline C) anglický jazyk & G) fyzika \\
\hline D) př́ŕrodopis & H) jiný: \\
\hline
\end{tabular}

9. Jaký předmět je pro Tebe při domácí výuce nejsnadnější? (Doplň název.)

10. Chybí Ti při domácí výuce nějaký předmět? (Pokud ano, doplň název předmětu.)

11. Jak v současné době učitelé hodnotí Tvou práci? (Můžeš vybrat více odpovědí.)

\begin{tabular}{lll}
\hline A) známkou & B) slovně & C) práci nehodnotí \\
\hline
\end{tabular}

12. Dostáváš na svou práci od učitele zpětnou vazbu?

A) ano, pošle mi s odstupem času správné řešení zadaných úkolů

B) ano, pošle mi zpět mé řešení zadaných úkolů s vyznačenými opravami

C) zpětnou vazbu od učitele nedostávám 


\section{Jak bys ohodnotil svůj výkon při domácí výuce?}

A) nemám problémy, zadané úkoly zvládám plnit samostatně

B) potřebuji mírnou pomoc od učitele/rodičů

C) potřebuji výraznou pomoc od učitele/rodičů

D) bez pomoci vůbec nezvládám řešit zadané úkoly

14. Těšíš se do školy?

\begin{tabular}{ll}
\hline A) ano & B) ne
\end{tabular}

15. Co se Ti na domácí výuce líbí/nelíbí? Doplň odpověd'.

\section{Příloha 2: Dotazník pro rodiče}

\section{Pohlaví}

A) muž

B) žena

\section{Věk}

\begin{tabular}{ll}
\hline A) méně než 24 let & D) 41-50 let \\
\hline B) 24-30 let & E) 51-60 let \\
\hline C) 31-40 let & F) 61 let a více
\end{tabular}

3. Vyhovuje Vám současný způsob výuky na dálku (od 11. 3. 2020)?

\begin{tabular}{ll}
\hline A) ano & B) ne
\end{tabular}

4. Kolik máte dětí školou povinných?
A) 1
D) 4 

B) 2
E) 5 a více
C) 3

5. Plní Vaše dítě/děti zadávané úkoly?
A) ano
B) ne

6. Kolik času denně Vám při současné výuce na dálku zabere příprava s dítětem (resp. dětmi) do školy?

\begin{tabular}{ll}
\hline A) méně než hodinu & C) cca 2 hodiny \\
\hline B) cca 1 hodinu & D) 3 a více hodin
\end{tabular}

7. Vyhovuje Vám způsob zadávání úkolů?

\begin{tabular}{ll}
\hline A) ano & B) ne
\end{tabular}

8. Komunikujete s učiteli?

$\begin{array}{ll}\text { A) ano } & \text { B) ne }\end{array}$

9. Jakým způsobem s učiteli komunikujete? (Můžete vybrat více možností.)

\begin{tabular}{ll}
\hline A) Bakaláři & E) telefon \\
\hline B) e-mail & F) Skype \\
\hline C) WhatsApp & G) jiné: \\
\hline D) Messenger & \\
\hline
\end{tabular}

10. Jak spolupráci s učiteli hodnotíte?

\begin{tabular}{ll}
\hline A) výborná & B) spíše špatná \\
\hline B) dobrá & D) špatná \\
\hline C) spíše dobrá & \\
\hline
\end{tabular}

11. Těšíte se, až půjdou děti do školy?

\begin{tabular}{ll}
\hline A) ano & B) ne \\
\hline
\end{tabular}


12. Co se Vám na domácí výuce líbí/nelíbí? Doplňte odpověd'.

\section{Př́loha 3: Dotazník pro učitele}

\section{Pohlaví}

\begin{tabular}{ll}
\hline A) muž & B) žena \\
\hline
\end{tabular}

\section{Věk}

\begin{tabular}{ll}
\hline A) méně než 24 let & D) 41-50 let \\
\hline B) 24-30 let & E) 51-60 let \\
\hline C) 31-40 let & F) 61 let a více \\
\hline
\end{tabular}

3. Délka praxe

\begin{tabular}{ll}
\hline A) $0-2$ roky & D) 16-20 let \\
\hline B) 3-5 let & E) 21 let a více \\
\hline C) 6-10 let & \\
\hline
\end{tabular}

4. Aprobace (doplňte)

5. Vyhovuje Vám současný způsob výuky na dálku (od 11. 3. 2020)?

\begin{tabular}{ll} 
A) ano & B) ne \\
\hline
\end{tabular}

6. Kolik dětí při domácí výuce vůbec nespolupracuje?

\begin{tabular}{ll}
\hline A) $0-3$ & C) $11-15$ \\
\hline B) $4-10$ & D) $16-20$ či více \\
\hline
\end{tabular}


7. Kolik času denně Vám zabere příprava při tomto způsobu výuky?

\begin{tabular}{ll}
\hline A) méně než hodinu & D) asi 4 hodiny \\
\hline B) asi 2 hodiny & E) 5 a více hodin \\
\hline C) asi 3 hodiny & \\
\hline
\end{tabular}

8. Kolik času denně Vám zaberou případné opravy prací žáků při tomto způsobu výuky?

\begin{tabular}{ll}
\hline A) méně než hodinu & D) asi 4 hodiny \\
\hline B) asi 2 hodiny & E) 5 a více hodin \\
\hline C) asi 3 hodiny & \\
\hline
\end{tabular}

9. Jaké materiály či prostředí používáte při výuce na dálku? (Můžete vybrat více možností.)

\begin{tabular}{ll}
\hline A) odkazy na učebnici a pracovní sešit & F) výukové programy \\
\hline B) vlastní pracovní listy & G) neplacené aplikace \\
\hline C) vlastní prezentace & H) placené aplikace \\
\hline D) vlastní videa & I) odkazy na www stránky \\
\hline E) DUMy & J) jiné: \\
\hline
\end{tabular}

10. Jak poskytujete žákům zpětnou vazbu?

\begin{tabular}{ll}
\hline A) postup žáků s nimi konzultuji & C) s odstupem posílám správné řešení \\
\hline B) zasílám zpět opravené úkoly & D) zpětnou vazbu neposkytuji \\
\hline
\end{tabular}

\section{Jak se žáky komunikujete? (Můžete vybrat více možností.)}

\begin{tabular}{ll}
\hline A) Bakalári & E) telefon \\
\hline B) e-mail & F) Skype \\
\hline C) WhatsApp & G) jiné: \\
\hline D) Messenger & \\
\hline
\end{tabular}

\section{Spolupracují s Vámi rodiče?}

\begin{tabular}{ll}
\hline A) ano & B) ne
\end{tabular}




\section{Jak spolupráci hodnotíte?}

\begin{tabular}{ll}
\hline A) výborná & D) spíše špatná \\
\hline B) spíše dobrá & E) špatná \\
\hline C) dobrá & \\
\hline
\end{tabular}

14. Jak s rodiči komunikujete? (Můžete vybrat více možností.)

\begin{tabular}{ll}
\hline A) Bakalári & E) telefon \\
\hline B) e-mail & F) Skype \\
\hline C) WhatsApp & G) jiné: \\
\hline D) Messenger & \\
\hline
\end{tabular}

15. Patříte do rizikové skupiny (senior ve společné domácnosti, zdravotní problémy apod.)?

\begin{tabular}{ll}
\hline A) ano & B) ne \\
\hline
\end{tabular}

16. Nastoupíte 25. 5. 2020 do školy?

\begin{tabular}{ll}
\hline A) ano & B) ne \\
\hline 17. Těšíte se do školy? & \\
\hline A) ano & B) ne \\
\hline
\end{tabular}

18. Co se Vám na domácí výuce líbí/nelíbí? Doplňte odpověd'. 